\title{
A Review: IMPACT of Floor Type and Bedding Materials on Performance of Dairy Animals
}

\author{
V. N. Gautam ${ }^{1 *}$, Shraddha Shrivastava ${ }^{2}$, G. P. Lakhani ${ }^{3}$, Rahul Sahehar ${ }^{3}$ \\ and Kuldeep Narayan Tripathi ${ }^{4}$
}

\author{
${ }^{1}$ Krishi Vigyan Kendra, Balrampur Indira Gandhi Krishi Viswavidyalaya, Raipur (C.G.) India \\ ${ }^{2}$ Department of Veterinary Physiology and Biochemistry, \\ College of Veterinary Science and Animal Husbandry, Jabalpur (M.P.) India \\ ${ }^{3}$ Department of Livestock Production and Management, \\ College of Veterinary Science and Animal Husbandry, Jabalpur (M.P.) India \\ ${ }^{4}$ IWMP Project Baikunthpur, Korea (c.g.) India \\ *Corresponding author
}

\section{A B S T R A C T}

\begin{tabular}{|l|}
\hline Ke y w o r d s \\
bedding materials, \\
milk yield, \\
Dairy farmers, \\
environmental \\
bacteria
\end{tabular}

Housing system and resting surface have influence on milk yield and reproductive performance as much as by feeding and keeping methods in dairy herd. Different types of bedding materials are used by livestock owners according to their availability, waste management, ease to use cost and environment. Good quality bedding materials contribute to better health and cow comfort. In recent years, many efforts have been undertaken to improve health and performance of dairy animals by modifying the housing environment. Different types of bedding materials like straw, limestone, sand, sawdust, wood chips, newspaper, manure solids, rice hulls etc. are used for dairy animals according to requirement. Dairy farmers prefer different floor type like rubber, stones, gravels, bricks, concrete, mates and mattress etc. for providing comfort to the animals according to their own status. Poorly designed stall and bedding facilities cause an increased risk of productive, reproductive performance and lameness in dairy animals including decrease in there resting phase (Cook et al., 2009). Depth and height of bedding materials is also an important factor for dairy cows comfort. A minimum of $25 \mathrm{~cm}$ depth of sand bedding is required (Buli et al., 2010). Deep bedded laying surface also provides more comfortable to the lame dairy cows (Jensen et al., 2015). A loss of about $70 \%$ in milk yield due to mastitis. Organic bedding materials contain higher number of environmental bacteria than inorganic materials. Inorganic bedding material is also best for cow comfort as compared to other as SCC is less in the inorganic bedding materials. Inorganic materials require less renewal than organic bedding. Bacterial counts and types found in bedding materials have a positive correlation with the bacteria present on the teat end (Zdanowicz et al., 2004).

\section{Introduction}

In order to ensure animal comfort which leads to increased production, the environment surrounding dairy cows must always be considered. The provision of properly designed stalls with comfortable bedding materials is one aspect of the dairy housing system which must be considered. The stalls must provide a place of rest for cows and a place where minimal harm is inflicted. Culling rates have been associated with 
increased instances of hock injuries and mastitis, all of which can be attributed to stall design and bedding material.

Provision of hard and unsuitable bedding in resting area resulted in lameness and leg injuries. Poorly designed stall and bedding facilities causes increased risk of productive, reproductive performance and lameness in dairy animals. Cows prefer softer bedding materials for lying and they spent longer time in lying down on soft surface as compared to hard surface (Manninen et al., 2002) and Tucker and Weary, (2004).

High producing dairy cows need to optimize their lying time. Disturbed rest may affect milk production by reducing the secretion of growth hormone, and reduced lying time is related to hoof health and lameness (Singh et al., 1994; Leonard et al., 1996).

\section{Why laying necessary?}

Cattle should be able and willing to lie down for an average of 11-14 hours a day. Lying enables better flow of blood to the teats as well as an increase in saliva production in the mouth which reduces the development of ruminal acidosis. A cow drinks approximately 20-30 gallons of water a day; as a result, a cow produces 108-308 liters of saliva a day.

This production is reduced when lying time is reduced. On average, 3 liters / minute of blood flows through the teats of standing cow while 5 liters / minute when they are lying down. As a result, the more a cow lies down, the udder function and milk production increases. The lying behavior of the cattle can depend on the time of day and particularly, on the stall design.

A reduction in the time cows spend resting can lead to physiological changes associated with stress which can ultimately affect the overall health and production of the cow. In particular, the stall design can strongly affect the standing and lying behavior, the frequency of injuries to the hooves, hocks, and knees of the cattle as well as mastitis. Therefore, providing a well-designed space for this behavior is important. Stalls for dairy cattle should provide the cow with a place which is clean, comfortable, dry, and should have resilient resting bedding materials for the ease of rising.

Standing time not only reduces the production of milk, it also has an adverse effect on the health of the cow claws. Standing for a prolonged time, due to the lack of space for the cow or discomfort of stalls, causes the blood pressure inside the claws to rise which is followed by a reduction in the perfusion of blood flow.

This causes an inadequate amount of oxygenation and nutrition of the hornproducing tissues. This reduction in circulation causes a decrease in the removal of toxins. This can lead to infections of the claw.

Relationship between daily time budget, cow comfort and performance of dairy cows

\section{Daily Time Budget}

A time budget is a log or diary of the sequence and duration of activities engaged in by an individual over a specified period, most typically the 24-hour day.

Proper rest has direct effect on performance of dairy animals as bedding and flooring provides soft area for animals to lay for rest and thus helps to improve their productive and reproductive performance. Dairy cows prioritize resting over other behaviors and cows that are deprived of lying shows 
behavioral and physiological disorders. Table -1 shows a daily time budget for a dairy cow suggested for better performance and health About 12-14 hours per day of lying / standing is essential for better health and different performance parameters of dairy animals. Lying behavior occupies about $50 \%$ of their daily time budget.

A lying time of 11 hours per day in free stall system is adequate for a lactating cow (Von Keyserlingket.al.,2012).Lying time ranges from $8 \mathrm{~h} / \mathrm{d}$ in pasture to $12.5 \mathrm{~h} / \mathrm{d}$ in tie stall (Charlton et.al.,2014) A resting time of 10 hours per day with deep straw-bedded yard is adequate lying time for a dairy cows Phillips and Rind (2001) suggested lying times of 10.9 to 11.5 hours per day in different type of housing system (Singh et.al.,1994)The important factors which direct affects the lying behaviors ,health status, and housing system, lying area design, overstocking, management and season.

It also affected by daily milking management practices like, milking time, milking periods and waiting periods etc. Lying time is higher during winter season than summer season (Metcalf et al., 1992). Increased lying may be helpful in more supply of blood to the udder, up to $24-28 \%$ more as compare to standing animals (Cook et al., 2009).

A higher blood flow in the mammary gland was reported during the laying period as compared to standing (4.56 1/ min vs. $3.561 /$ min.), Laying deprivation resulted in stress to dairy animals, which affects productivity and physiological status. Such type of stress results in low level of growth hormone with elevated level of plasma cortisol level. Reduced lying time results in low feed intake and lower milk production. High producing dairy cow requires more time for eating to produce more milk. Cow spends more time in feeding when soft and comfortable bedding materials were provided (Tucker et al., 2006).

\section{Effect of bedding materials on microbial growth}

In bedding materials, presence of large number of different types of bacteria results in mastitis and increased somatic cell count [SCC] in milk. Mastitis is an economically important disease, which directly affects the quality and quantity of milk. Generally, in a dairy cow herd, incidences of sub clinical mastitis is generally more than clinical mastitis and accounts ranges from 19 to 78 percent.

Sub clinical mastitis is associated with prevalent type of udder infections in dairy cows. In Indian condition, incidences of subclinical mastitis are more about $10-50 \%$ in dairy cows. A loss of about $70 \%$ in milk yield during to mastitis condition (Sharma et al., 2012). Organic bedding materials contain higher number of environmental bacteria than inorganic materials. Inorganic bedding material is also a best for cow comfort. SCC is less in the inorganic bedding materials (Rowbotham et al., 2015). Inorganic materials requires less changing than organic bedding.

Lowest case of mastitis is found in the sand and rubber floor bedded animals than concrete floor bedded animals. The lowest clinical mastitis case was observed in rubber flooring than concrete and sand bedding .It was also found that rubber flooring is better to reduce the chance of clinical mastitis. The case of clinical mastitis was 14 percent higher in concrete floor than rubber mats (Valde et al., 1997)

In a comparison of the effect of deep bedded new sand, recycled sand and manure solid on mastitis incidence in primiparous Holstein cows, and found that quarters of new sand 
bedded animals have more survival time for clinical mastitis than other two bedding. The physical and nutritional conditions of bedding materials also affect the growth of microorganism. A close relationship is observed between quality of bedding material and bacterial population (Zdanowicz et al., 2004). Coliform and total bacterial counts activities are higher in indoor housing than outdoor or pasture. Manure bedding supported the growth of microorganism as it contains large amount of nutrient. it was found that recycled manure solid was being used as bedding materials because SSC was lowest than other bedding materials.

\section{Concrete floors}

Concrete is the most basic flooring material. Generally, it is just the surface of the slab that is poured directly onto the gravel or dirt bed $\&$ some incorporate crushed stone or gravel for a rougher surface in order to install the foundation of a building.

Concrete floor that are roughened in an attempt to preclude slippage can wear hooves excessively, and smooth floors do not offer sufficient traction. There is a fine line between a concrete floor surface that is too rough and causes injury due to abrasion and one that is too smooth and causes injury because of inadequate footing. Experience has shown that the finish on a floor is often the biggest mistake made during barn construction. Rough finished floors will speed foot wear by up to 20 percent, with cows being culled in three weeks of new barn occupancy due to lameness .

Desirable characteristics of a grooved concrete floor include:

Flat surface between grooves,

Smooth surface between grooves,

Smooth groove edges with a right angle between the groove and the floor surface,

Proper groove width, spacing, and depth.

\section{Saw dust and wood shavings}

Saw dust or wood dust is a by-product or waste product of woodworking operations such as sawing, milling, planning, routing, drilling and sanding. It is composed of fine particles of wood (IARC 1995).These operations can be performed by woodworking machinery, portable power tools or by use of hand tools.

Wood-based products seem to be the most popular bedding material choices for dairy producers. Availability of kiln dried sawdust and wood shavings can be problematic in some areas. Wood products provide good cow comfort and work well in most waste management systems. The biggest disadvantage is that sawdust and/or wood shavings provide an environment for mastitis causing microorganisms.

Use of green, hardwood sawdust containing bark material has been associated with Klebsiella mastitis .Bacterial numbers often increase with decreasing particle size. Very fine sawdust from furniture construction may be nearly sterile prior to use but the small particle size supports very rapid growth of bacteria requiring more intensive bedding maintenance.

\section{Straw}

Dried stalks of grain, used especially as fodder or as material for thatching, packing, or weaving. Chopped straw is a widely-used bedding material for dairy cow cubicle housing in the developed country, and when clean, dry, well-stored straw is used and managed correctly it can provide a comfortable environment for cattle bedding 
(Graves et al., 2009). However, where straw beds are allowed to become heavily soiled, particularly in deep-bedded yards, the bedding has the potential for becoming an effective medium for pathogens responsible for causing infectious foot problems. (Pithua et al., 2009) Further problems can result from straw and muck hardening onto hooves, particularly between claws and where fissures occur in cleft, enabling these pathogens to infect the foot more easily.

Long straw has been used successfully in calving pens. Straw must be chopped to work well installs. Straw, whether long or chopped can be too bulky for many manure systems. Use of straw bedding is often associated with increased levels of mastitis from Streptococcus uberis infections.

\section{Paper-based bedding materials}

A variety of paper-based products are used for livestock bedding, including shredded waste paper, paper pulp and specially-designed proprietary granulated bedding products. Specially-designed granulated materials can possess excellent characteristics that make them suitable as dairy cow bedding (Endre, 2012).

The latent alkalinity of some paper-based products also has a disinfectant effect and can help to control pathogens. Paper pulp can set hard, and can produce an undesirable uneven surface. When wet it can heat-up to provide good conditions for pathogens to flourish (Bernard et al., 2002).

Paper products are relatively inert initially. The biggest drawback is that they tend to stick to cows and mat up when they get damp with urine or moisture. Bacterial numbers can increase within 24 hours of contamination.

\section{Wood products}

It include wood shavings the waste obtained when wood is shaped or planed using carpentry tools or machines like planers and milling machines. Wood shavings do not have a fixed size or shape. Generally they are flat thin curls that peel off the surface of wood when it is run through a planning machine or planer.

A variety of composite wood products that have been developed. Plywood and laminated veneer lumber use thin sheets of wood veneer as lamina (layers) for panel-type and lumbertype products, respectively. The conversion efficiency associated with wood veneer production is higher than that of lumber production. Oriented strand products use thin wafers of wood as a raw material (Haygreen et al., 1996). In this case, low-grade trees are reduced to thousands of small strands, and the strands are subsequently pressed together with adhesive into panel products. When trees are reduced to strands, conversion efficiency is 90 to 95 percent (Wood Handbook, 1995).

\section{Hydrated lime and disinfectant powders}

Hydrated or "slaked" lime consists primarily of calcium hydroxide $[\mathrm{Ca}(\mathrm{OH}) 2]$ and magnesium hydroxide $30[\mathrm{Mg}(\mathrm{OH}) 2]$ at $50-$ $95 \%$ and $0-50 \%$ of the substance, respectively (Lafarge, 2011). High purity forms of the 31 substance contain greater than $90 \%$ calcium hydroxide.(Santosh, 2005).In addition, 32 smaller amounts of silicon (e.g., $\mathrm{SiO} 2$ ), iron (e.g., $\mathrm{Fe} 2 \mathrm{O} 3$ ), aluminum (e.g., Al2O3) and magnesium (e.g., $\mathrm{MgO}) 33$ oxide compounds, as well as calcium and magnesium carbonates ( $\mathrm{CaCO} 3$ and $\mathrm{MgCO} 3)$, are frequently 34 observed in hydrated lime samples (Lafarge, 2011; Santosh, 2005). Lime is used sparingly with other bedding materials. It has the potential to dry-out and damage teat and udder skin and so must be adequately covered with chopped straw or sawdust, but is very useful in drying-out soiled wet patches on cubicle beds and 
controlling bacterial levels.

\section{Hulls}

Rice hulls (or rice husks) are the hard protecting coverings of grains of rice. In addition to protecting rice during the growing season, rice hulls can be put to use as building material, fertilizer, insulation material, or fuel. Rice hulls are part of the chaff of the rice. It constitutes about $20 \%$ of the weight of rice and its composition is as follows: cellulose (50\%), lignin (25\%-30\%), silica (15\%-20\%), and moisture (10\%-15\%) (Chuah et al., 2005).

Rice hulls provide comfortable bedding for cattle. Hulls can be relatively inexpensive, easy to handle, and work well in liquidmanure handling systems (Jenkins., 1998). The big disadvantage is that rice hulls can have high carbohydrate levels, which readily support the growth of microorganisms that cause mastitis.

\section{Composted or dried manure solids}

Manure solids are usually referred to as compost. They are produced in three ways: one process separates the solids from the manure after anaerobic digestion, another separates the solids and then treats them through an accelerated composting process using a drum composter, and the third separates the solids without any treatment process.

Approaches to separate solids from the liquid of cow manure have been known for a while and the use of the dewatered material as bedding is increasing in popularity on dairy farms (Garcia and Diaz-Royón, 2014; Leach et al., 2015).Following solid-liquid separation, fresh recycled manure solids (RMS) may be used directly in stalls without treatment or subjected to a composting procedure before being placed under the cows (Cole, 2015; Harrison et al., 2008; Husfeldt et al., 2012).

\section{Recycled manure solids}

In recycled manure solids manure is scraped or flushed from stalls. In some processes, the flushed material moves on to anaerobic digestion to reduce the bacteria content and odor of the material. The slurry then goes through a solid/liquid separation process. This is most commonly done with a screw press, centrifuge, or slope screen that separates the coarse fibers from the liquid portion. The resulting material is a recycled manure solid that can be used as bedding.

With the advent of methane digesters, recycled manure solids have grown in popularity. One main advantage is the elimination of the finer manure solids from the bedding component. This creates a fluffier material that reduces compaction and is less able to cling to teat skin. The moisture level coming off the digester is rather high (70\%). Using this product fresh on a daily basis can be an excellent bedding source

\section{Sand}

Sand is loose granular substance, typically pale yellowish brown, resulting from the erosion of siliceous and other rocks and forming a major constituent of beaches, river beds, the seabed, and deserts

Many consider sand to be the gold standard of bedding materials. It is inert and does not support the growth of bacteria, (Bell, 2007). Sand should be of builders' quality and contain little or no silt or clay. When properly maintained sand provides a very comfortable medium for bedding. Sand particles tend to move rather than compact, forming a more comfortable resting surface that conforms to 
the cow's body. Bacteria counts of used sand bedding are often significantly lower than inorganic bedding materials (Van der Tol, 2005). Lower bacteria counts are associated with reduced rates of new infections with environmental pathogens. A big disadvantage to using sand is that it settles at the bottom of lagoons and manure collection pits and can cause excessive wear on manure spreaders, pumps, and separators.

\section{Additives}

Additives are substance added to something in small quantities to improve or preserve it. or Agent or factor that, when combined with other agents and factors, adds to their cumulative effect or strength usually by a known degree or extent. This is added to enhance the performance, improve the appearance, extend the shelf life, of used material

Additives have been used in an attempt to extend the life of or lower the bacteria counts of bedding materials (Shah et al., 2018). This is often done when addressing a clinical mastitis crisis situation. Hydrated lime added to sawdust or shavings has been shown to increase bedding $\mathrm{pH}$, and reduce its water content. Adding one to two pounds of hydrated lime per stall to bedding inhibited bacterial growth but may or may not reduce the incidence of clinical mastitis. The effect of added lime is short lived (less than 24 hours) and requires that lime be added daily

\section{Rubber mats}

A Rubber mat is a piece of fabric material that generally is placed on a floor or other flat surface and it is made from the synthetic rubber (often referred to as "vinyl" or "thermoplastic") or textile materials. Cows spend 11 to $13 \mathrm{~h} / \mathrm{d}$ standing in freestall housing systems (Ito et al., 2009). Concrete is the most common flooring material (USDA, 2009) and is a known risk factor for hoof and leg lesions (Vokey et al., 2001; Somers et al., 2003) and lameness in cattle (Cook, 2003; Vanegas et al., 2006). Use of alternatives to concrete, such as rubber, has increased during the last 2 decades (USDA, 2009) and is thought to improve cow comfort. Cows walk faster, take longer strides, and slip less (Telezhenko and Bergsten, 2005; Rushen and de Passillé, 2006) on rubber floors compared with concrete. These benefits of rubber, namely in walking speed, are more marked in lame cows compared with sound ones (Flower et al., 2007).

\section{Pre-cast concrete slatted floors}

Pre-cast concrete slatted floors (slats) were primarily developed to reduce the amount of daily labor required to clean barn alleys and as a means to passively transfer liquid manure directly to a storage or gravity collection gutter located immediately below the barn alley. Slats have been used in most cowfrequented areas associated with confined housing systems including alleys between rows of stalls, adjacent to feeding surfaces, transfer lanes, and in milking center holding areas. Additionally, some producers locate slats at the ends of poured-in-place concrete alleys with the intention of using them as scraped manure drop sites. However, slats are not designed for this application, and therefore this practice is not recommended. The relatively large volume of manure deposited in an alley will not effectively drop through the few narrow slots of a slatted floor located at the alley's end. A 8 to 10 inch wide continuous slot positioned transversely in each alley will provide adequate space for scraped manure to drop through into a storage pit or gravity flow pipe located below.

Milk yield and its quality

Milk yield and its compositional quality 
directly depend on udder health and its immunity (Szencziova et al., 2013). No any positive effect was observed related to milk parameters in many experiments. Nonsignificant effect of rubber or concrete floors was observed on different milk parameters (Kremer et al., 2007).

Similarly, no any significant effect of bedding materials was observed on milk yield and milk composition in Vrindavani cross bred cow (HF/Jersey/BS X Hariana), (Upadhyay et al., 2015). (Kremer et al., 2012) had observed that Milk yield, fat yield, fat \%, and Protein yield was non-significantly increased by using rubber mat than concrete floor. And reported that only protein $\%$ significantly increased in rubber mat but no any specific cause was observed during experiment

\section{Reproductive performance}

Reproductive performance of dairy animals also depends on floor type. In most of the dairy farms, reduced reproductive efficiency and culling problems has been observed due to lameness. With use of some bedding materials in free stall house, fertility was better compared to tie stall house (Nogalski., 2006). Housing on concrete is resulted in reduced display of Mounting, standing and oestrus duration reduces on concrete floor (Britt et al., 1986).

Table.1 Daily time budget for a dairy cow (Grant, and Albright, 2000)

\begin{tabular}{|l|l|}
\hline Activity & Time $/ \mathbf{2 4}$ hours \\
\hline Lying/standing & 12 to $14 \mathrm{~h}$ \\
\hline Eating & 3 to $5 \mathrm{~h}$ \\
\hline Drinking & $30 \mathrm{~min}$ \\
\hline Rumination & 7 to $10 \mathrm{~h}$ \\
\hline Social interaction & 2 to $3 \mathrm{~h}$ \\
\hline Manage mental activities & 2.5 to $3.5 \mathrm{~h}$ \\
\hline
\end{tabular}

\section{Different bedding materials}
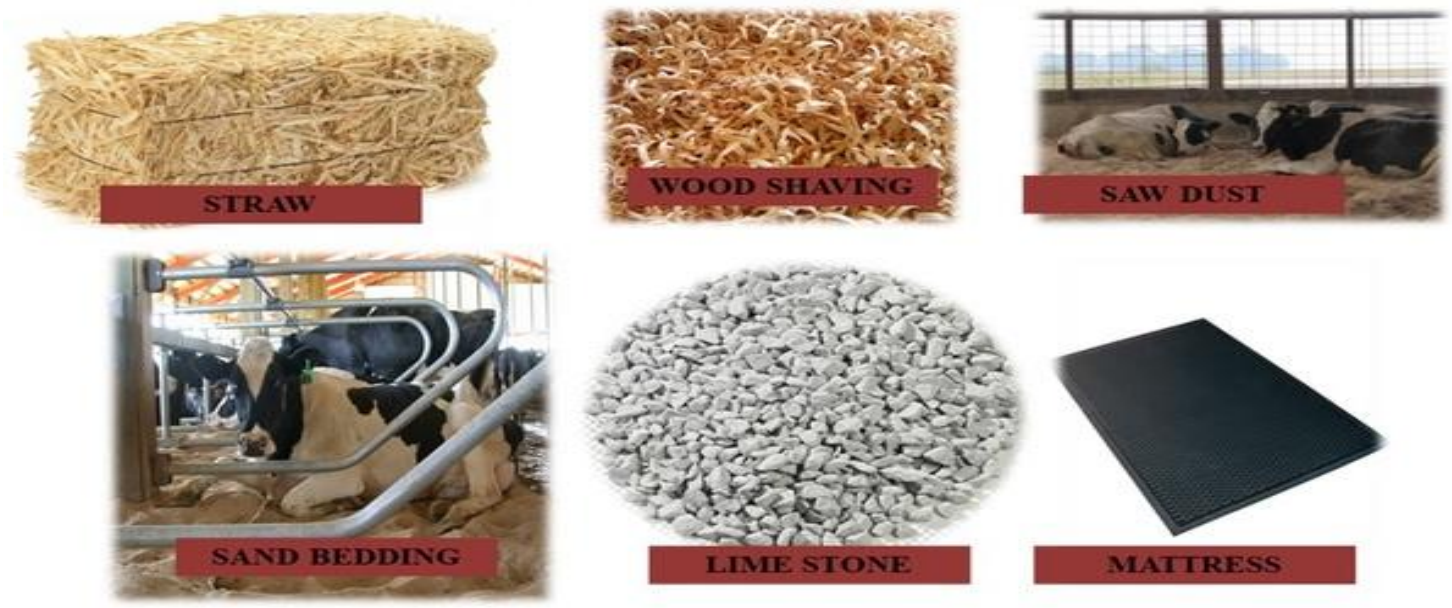

Fig.1 Different bedding materials 
Reproductive activity like duration of oestrus and number of mounts was significantly better in rubber-covered slats, pasture and straw as compared to concrete floor (Larkin et al., 2003). They also found that dirt floor is helpful for mounting activity. Similarly, housing of dairy animals in compost bedded pack resulted in reduction in calving interval, days open and higher milk production than convenient bedding housing (Black et al., 2011).In straw used calving pen subclinical endometritis was $10.7 \%$ lower compared to other type bedding like paper, sawdust or sand.

\section{Lameness}

The lameness has a direct negative effect on profitability of a dairy farm (Cozzi et al., 2013), as it directly affects the milk yield and reproductive performance of dairy cows. The effect of lameness associated with reduced milk yield, premature culling, and increased calving to first service time, fertility problems and huge economic loss etc.

Prolonged standing on concrete is a major predisposing factor for lameness (Singh et al., 1993). Hard floor results in lameness problem and causes white line damage and horn lesion. In dairy animals, slipping problem was higher in concrete with fully slatted floor than perforated floor and perforated floor with rubber mattress (Cozzi et al., 2013) .Similarly, sole hemorrhages problem is less in the rubber flooring and highest in concrete (Haufe et al., 2012).

Claw injuries directly impact negatively on the reproduction and production of the animals. A dairy animal reduces milk production due to sole ulcer. Lame cows had reduced in 1st service conception rate and pregnancy rate, increased ovarian cysts. So these result showed a reduction in reproductive efficiency due to lameness
(Hernandez et al., 2005). In dairy farm, huge economic loss occurs due to higher rate of culling and fertility problems. Laying behavior of dairy cows is highly affected by lameness (Thomsen et al., 2012). A lying time reduces 5 hours per day due to foot lesion scores (Leonard et al., 1996).

\section{References}

Bell, N., (2007)Applying principles of Hazard Analysis Critical Control Point (HACCP) system to reduce lameness in UK dairy heifers. Cattle Practice 11 (4), 385.

Black R.A., Taraba J.L. Day G.B., Damasceno F.A. and Bewley J.M. (2011).The relationship between compost bedded pack performance, management, and bacterial counts Journal of Dairy Science, 96(12), 8060-8074.

Britt, J.H., Scott R.G., Armstrong J.D. and Whitacre M.D. (1986) Determinants of estrous behavior in lactating Holstein cows Journal of Dairy Science, 69, 2195-2202.

Charlton, G.L., Haley D.B., Rushen J. and De Passille A.M. (2014) stocking density milking duration and laying time of lactating cows on canadin free stall dairy farm.Journal of Dairy Science,97, 26942700

Chuah, T G, Jumasiah A, Katayon S, Choong T S $\mathrm{Y}$ (2005). Rice husk as a potentially lowcost biosorbent for heavy metal and dye removal: an overview. Desalination. 175, 305-316.

Cook, N.B. (2003). Prevalence of lameness among dairy cattle in Wisconsin as a function of housingtype and stall surface.Journal of Animal Veterinary.Medicine Association.223:13241328

Cook, N. B., and Nordland, K. V. (2009). The influence of the environment on dairy cow behaviour,claw health and herd lameness dynamics. Veterinary Journal 179:360369.

Cole, K. J.,(2015). Bacterial counts in composted and fresh recycled dairy manure bedding. The Ohio State University, Animal Sciences, Columbus, OH, USA 
Cozzi G., Tessitore E., Contiero B., Ricci R., Gottardo F. and Brscic M.(2013). Alternative solutions to the concrete fullyslatted floor for the housing of finishing beef cattle: effects on growth performance, health of the locomotor system and behavior. Veterinary Journal, 197(2), 2115.

Flower, F.C., A.M. de

Passillé, (2007), D.M. Weary, D.J. Sanderson, J. Rus henSofter, higher-friction flooring improves gait of cows with and without sole ulcers Journal of Dairy Science., 90 pp. 12351242

Garcia, A., and F. Diaz-Royón.(2014). Recycled manure solids as bedding. Retrieved from http://articles.extension.org/pages/70319/re cycled-manure-solids-as-bedding

Harrison, E., J. Bonhotal, and M. Schwarz. (2008). Using manure solids as bedding. Cornell Waste Management Institute. Ithaca, NY, USA

Haufe H.C., Gygax L., Wechsler B., Stauffacher M. and Friedli K. (2012).influence of floor surface and access to pasture on claw health kept in cubical housing system on dairy cow. Prevventive Veterinary Medicine, 105, 85- 92.

Hernandez J.A., Garbarino E.J., Shearer J.K., Risco C.A. and Thatcher W.W. (2005) Comparison of milk yield in dairy cows with different degrees of lameness. Journal of the American Veterinary Medical Association 227(8): 1292-1296

Husfeldt, A. W., M. I. Endres, J. A. Salfer, and K. A. Janni.(2012). Management and characteristics of recycled manure solids used for bedding in Midwest freestall dairy herds.Journal of Dairy Science. 95(4):2195-2203.

Haygreen, John G., and Jim L. Bowyer. (1996).Forest Products and Wood Science: An Introduction, 3rd ed. Ames, IA: By Wiley \& Sons ISBN10: 0813822564.Iowa State University Press

Kremer, P. V., Scholz A. M., Nüske S. and Förster M. (2012). Do mats matter? Comparison offertility traits and milk yield in dairy cows on rubber or concrete flooring. ArchiveTierzucht.55(5):438-449.

Kremer, P.V., Nueske, S., Scholz, A.M., Foerster,
M., (2007). Comparison of claw health and milkyield in dairy cows on elastic or concrete flooring.Journal of Dairy Science., 90, 4603-4611.

Larkin, J., Sreenen, J.M., Boland, M.P. and Diskin, M.G. (2003).Effect of underfootsurfaceconditions and group size on expression of oestrus in heifers. Progressive Agriculture ResearchForum., p. 85.

Lafarge, 2011; Lafarge,(2011)., Material Safety Data Sheet: Lafarge Hydrated Lime. Lafarge North America Inc. Retrieved 648 December 15, 2014 from http://www.lafargena.com/MSDS_North_America_English

Leonard, F.C., O'Connell, J.M. and O'Farrell, K.J. (1996).Effect of overcrowding on claw health infirst-calved Friesian heifers.British Veterinary Journal 152: 459-472.

Leach, K. A., S. C. Archer, J. E. Breen, M. J. Green, I. C. Ohnstad, S. Tuer, and A. J. Bradley.(2015). Recycling manure as cow bedding: Potential benefits and risks for UK dairy farms. Veterinary Journal 206 (2):123-130

Manninen, E., De Passille A.M., Rushen J., Norring M. and Saloniemi H. (2002). The effect of diet and housing on the development of sole haemorrhages, white line haemorrhages and heel erosions in Holstein heifer. Applied Animal. Behaviour Science, 75, 281-292.

Nogalski, Z., (2006). Bedding materials and udder health. Mastitis Module Fact Sheet. Acta Scientiarum Polonorum Zootechnica, 5, 97106.

Pithua, P., Wells, S.J., Godden, S.M. and Raizman, E.A. 2009. Clinical trial on type of calving pen and the risk of disease in Holstein calves during the first $90 \mathrm{~d}$ of life. PreventiveVeterinary Medicine.,89(1-2):815.

Rushen, J., E. Pombourcq, A.M. de Passillé (2006), Validation of two measures of lameness in dairy cows Applied Animal Behavior Science. 106 pp. 173-177

Santosh,(2005)., Hydrated Lime. Santosh Chemicals. Retrieved December 12, 2014 from

Shah, GA., Shah GM, Rashid MI, Groot JCJ, Traore B, Lantinga EA.(2018)Bedding additives reduce ammonia emission and 
improve crop $\mathrm{N}$ uptake after soil application of solid cattle manureJ Environ Manage. 209:195-204

Singh, S.S., Ward W.R., Hughes J.W., Lautenbach K. and Murray R.D. (1993). Behavior of dairy cow in a straw yard related to lameness. Veterinary Records, 133, 204-208. Research, 5, 75-79.

Singh, S.S., Ward W.R., Hughes J.W., Lautenbach K. and Murray R.D. (1994). Development of claw traits and claw lesions in dairy cows kept on different floor systems. Veterinary Records, 135, 251-253.

Szencziova, I., Strapak P., Stadnik L., Duchacek J, and Beran J. (2013) Effect of different flooring systems on claw conformation of dairy cows.Journal of Dairy Science 92, 2625-2633. Annals of animal Science, 13, 973-795.

Telezhenko, E., and C. Bergsten (2005),Influence of floor type on the locomotion of dairy cowsApplied Animal Behavior Science., 93 pp. 183-197.

Thomsen, P.T., Munksgaard L. and Sorensen J.T. (2012). Effects of pen floor and class of live weight on behavioural and clinical parameters of beef cattle. Veterinary Journal, 193, 644-647.

Tucker, C.B. and Weary D.M. (2004). Differences in behaviour, health status and productive performance of beef young bulls housed on different type of floor and assessed in two fattening phases.Journal of Dairy Science, 87, 2889-2895.

Tucker,

C.B., D.M. Weary, A.M. de Passillé, B. Campbell, J. Rushen (2006),Flooring in front of the feed bunk affects feeding behavior and use of freestalls by dairy cows Journal of Dairy
Science., 89 pp. 2065-2071.

Upadhyay, D., Singh M., Patel B.H.M, Gaur G.K., Verma M.R., Bharti P. and Madkar A.(2015). Factors influencing milk production of local goats of Rohilkhand region of Uttar Pradesh under semi intensive systemJournal of Animal

Valde, J.P., Hird D.W. Thurmond M.C. and Osteras O.(1997). Cubicle Refusal and Rearing Accommodation as Possible Mastitis Risk Factors in Cubicle-Housed Dairy HeifersActaVeterinariaScandinavica, 38,181-192

Vanegas, J., M. Overton, S.L. Berry, W.M. Sisch o(2006), Effect of rubber flooring on claw health in lactating dairy cows housed in free-stall barnsJournal of Dairy Science., 89 pp. 4251-4258.

Van der Tol, P.P.J., Metz, J.H.M., Noordhuizen- Stassen, E.N., Back, W., Braam, C.R., Weijs, W.A. (2005) 'Frictional forces required for unrestrained locomotion in dairy cattle', Journal of Dairy Science, 88, 615- 624

Von Keyserlingk, M.A., Barrientos G., Ito A.K., Galo E. and Weary D.M. (2012). A study on cow comfort and risk for lameness and mastitis in relation to different types of bedding materials. Journal of Dairy Science, 95,7399-7408

Wood Handbook.,(1999). Wood as an Engineering Material. Publication No.FPLGTR-113. Madison, WI: U.S. Forest ServiceEndre,2012).

Zdanowicz, M., Shelford J.A., Tucker C.B., Weary D.M. and Von Keyserlingk M.A. (2004). Tie-stall design and its relationship to lameness, injury, and cleanliness. Journal of Dairy Science, 87, 1694-701.

\section{How to cite this article:}

Gautam. V. N., Shraddha Shrivastava, G. P. Lakhani, Rahul Sahehar and Kuldeep Narayan Tripathi. 2020. A Review: IMPACT of Floor Type and Bedding Materials on Performance of Dairy Animals. Int.J.Curr.Microbiol.App.Sci. 9(05): 1524-1534.

doi: https://doi.org/10.20546/ijcmas.2020.905.173 